\title{
Social Bonds for Sustainable Development: A Human Rights Perspective on Impact Investing
}

\author{
Stephen Kim PARK*
}

\begin{abstract}
This article analyses the human rights implications of impact investing, which aims to create positive social and environmental impacts in addition to financial returns. Reflecting growing awareness of the capacity of the global capital markets to advance sustainable development, companies and institutional investors are seeking new financial instruments and strategies. This article focuses on social bonds, a prominent and illuminating example of this phenomenon. Social bonds are debt securities sold to investors whose proceeds are used to finance projects with a defined social benefit such as affordable housing, education, food security, and access to healthcare. To analyse social bonds in the context of human rights, this article proposes a framework for evaluating human rights factors in impact investing and applies it to the social bond market. It finds that current standards and practices do not adequately account for the human rights implications of social bonds. In light of these observations, this article suggests reforms to the social bond market that enhance investor assessment, external assurance, and impact-maximizing leverage.
\end{abstract}

Keywords: social bonds, impact investing, sustainable finance, Sustainable Development Goals, private governance

\section{INTRODUCTION}

This article considers how private investment through the global financial markets can support sustainable development in a manner that comports with human rights. The United Nations' Sustainable Development Goals (SDGs) represent the most ambitious and wide-ranging effort to fulfil human rights in international development. ${ }^{1}$ Underlying the SDGs are rights to food, health, education, gender equality, clean water and sanitation, and decent work protected under international human rights

* Assistant Professor of Business Law and Satell Fellow in Corporate Social Responsibility, University of Connecticut. A prior version of this article was presented at the Global Business and Human Rights Scholars Association Annual Conference in 2017. Support was provided by the Business and Human Rights Initiative at the University of Connecticut.

1 '2030 Agenda Transforming our World: The 2030 Agenda for Sustainable Development' (2030 Agenda), A/RES/70/1 (25 September 2015), preamble ('[The SDGs] seek to realize the human rights of all ...'). 
law. $^{2}$ Despite the vagueness of their express commitments, ${ }^{3}$ the formulation and implementation of the SDGs make clear their grounding in human rights. ${ }^{4}$

Consistent with the United Nations Guiding Principles on Business and Human Rights (Guiding Principles), ${ }^{5}$ the SDGs embrace the positive role of private business activity to achieve sustainable development. ${ }^{6}$ Arguably most important among business actors is the financial sector. The financial resources required to meet the 17 SDGs and their 169 associated targets are enormous, amounting to approximately US\$5 trillion to US\$7 trillion in global investment annually. ${ }^{7}$ This is particularly daunting for developing countries, which face an annual funding gap of US\$2.5 trillion. ${ }^{8}$ Without a great leap in private sector finance, the 'SDG investment gap' is insurmountable. ${ }^{9}$ New financing strategies and instruments are crucial to bridge this gap. ${ }^{10}$

In particular, institutional investors, such as pension funds, mutual funds and insurers which collectively hold US\$85 trillion in assets worldwide - are key actors. ${ }^{11}$ Impact investing focuses on opportunities to generate positive social and environmental impacts in addition to financial returns through capital investments. ${ }^{12}$ Institutional investors increasingly seek to invest in companies, organizations, funds and projects based on this objective, including those aligned with the SDGs. ${ }^{13}$ However, impact investing is vulnerable to instances or suspicions of 'whitewashing' - i.e., profit- or brand-enhancing

2 United Nations Office of the High Commissioner for Human Rights, 'Transforming Our World: Human Rights in the 2030 Agenda for Sustainable Development', http://www.ohchr.org/Documents/Issues/MDGs/Post2015/ TransformingOurWorld.pdf (accessed 20 April 2018).

3 See Thomas Pogge and Mitu Sengupta, 'The Sustainable Development Goals (SDGs) as Drafted: Nice Idea, Poor Execution' (2015) 24 Washington International Law Journal 571, 575-76.

4 Gillian MacNaughton and Diane F Frey, 'Decent Work, Human Rights and the Sustainable Development Goals' (2016) 47 Georgetown Journal of International Law 607, 644-46.

5 Human Rights Council, 'Guiding Principles on Business and Human Rights: Implementing the United Nations “Protect, Respect and Remedy" Framework' (Guiding Principles), A/HRC/17/31 (21 March 2011).

62030 Agenda, note 1, para 67.

7 United Nations Conference on Trade and Development, World Investment Report 2014 Investing in the SDGs: An Action Plan (Geneva: UNCTAD, 2014) 140.

8 Ibid.

9 Jessica Davis Pluess, Smruti Govan and Paula Pelaez, Conditions for Scaling Investment in Social Finance (San Francisco: Business for Social Responsibility (BSR), September 2015) 9, https://www.bsr.org/reports/ BSR_Conditions_for_Scaling_Social_Finance_2015.pdf (accessed 20 April 2018).

10 See United Nations, Secretary-General, Press Release, 'New United Nations-Private Sector Partnership Platform to Generate Financing Solutions for Sustainable Development Goals', SG/2233-ENV/DEV/1736 (10 October 2016) (announcing the launch of a financial innovation platform to drive investment from governments, development finance institutions, foundations, as well as institutional investors and other private actors). As stated by the UN SecretaryGeneral, '[t]his global initiative can support the identification and piloting of innovative finance instruments that can drive investment and support well thought-out SDG interventions'.

11 See Benjamin J Richardson and Maziar Peihani, 'Universal Investors and Socially Responsible Finance: A Critique of a Premature Theory' (2015) 30 Banking \& Finance Law Review 405, 409-11 (describing fiduciary capitalism).

12 See Paul Brest and Kelly Born, 'When Can Impact Investing Create Real Impact?' Stanford Social Innovation Review (Fall 2013), 24 (defining impact investing as 'actively placing capital in enterprises that generate social or environmental goods, services, or ancillary benefits such as creating good jobs, with expected financial returns ranging from the highly concessionary to above market'). See also Olaf Weber, 'Impact Investing' in Othmar M Lehner (ed.), Routledge Handbook of Social and Sustainable Finance (New York: Routledge, 2017) 85, 85-86 (distinguishing impact investing from conventional investing and philanthropy).

13 See Casey O'Connor and Sarah Labowitz, 'Putting the "S" in ESG: Measuring Human Rights Performance for Investors' (New York: Center for Business and Human Rights, Stern School of Business, New York University, March 2017) 4-5; Principles for Responsible Investment, 'What Do the UN Sustainable Development Goals Mean for Investors?' (UNEP FI, UNCG, 2016), https://sdg-investments.com/fileadmin/user_upload/pri-sdg-relation.pdf, 3. 
rhetoric despite neutral or even negative performance enabled by unenforced shirking of declared social commitments. ${ }^{14}$

Amidst these challenges, this article focuses on social bonds, a new and emerging form of impact investing. ${ }^{15}$ Social bonds are bonds whose proceeds are used to finance projects with a defined social impact. ${ }^{16}$ Their social impact is established through mitigation of a negative social impact and/or achievement of a positive social outcome such as housing, employment generation, food security, health and education. ${ }^{17}$ While the social bond market currently constitutes a very small portion of the global capital markets, totalling less than US $\$ 16$ billion in total issuances, ${ }^{18}$ it is poised to substantially expand as banks and corporations join government agencies and multilateral institutions as issuers of social bonds. ${ }^{19}$

There is a growing literature on the intersection of banking and human rights in the context of the Guiding Principles and other human rights frameworks. ${ }^{20}$ However, the impact of human rights in the financial sector extends far beyond the activities of global financial institutions. Building on these observations and arguments, this article extends and applies them to address the human rights challenges posed by the complex, heterogeneous and fragmented global capital markets. ${ }^{21}$ The social bond market, in its current form, reveals the problem of equating the achievement of positive social outcomes with the protection of universal human rights. ${ }^{22}$ Current regulatory standards and industry practices fail to adequately account for the human rights implications of social bond-financed projects. As a result, social bonds do not ensure respect for human rights as set forth in the Guiding Principles and the SDGs.

This article proceeds as follows. Part II describes the growing role of the private capital markets in financing sustainable development, taking note of the human rights implications of this phenomenon. Part III analyses the emergence and growth of the social bond market and shows how social bonds align with the SDGs. Part IV proposes a

\footnotetext{
14 See John G Ruggie, 'Multinationals as Global Institution: Power, Authority and Relative Autonomy' (2017) Regulation and Governance, https://onlinelibrary.wiley.com/doi/10.1111/rego.12154/full (accessed 20 April 2018) (referring to allegations of whitewashing by critics of corporate social responsibility).

15 See Weber, note 12, 91-92 (examining green bonds as a prominent form of impact investing).

16 International Capital Markets Association, 'The Social Bond Principles 2017 - Voluntary Process Guidelines for Issuing Social Bonds' (Social Bond Principles) (2 June 2017), https://www.icmagroup.org/assets/documents/ Regulatory/Green-Bonds/SocialBondsBrochure-JUNE2017.pdf (accessed 20 April 2018).

17 Ibid.

18 Ulrik Ross, 'Social Bonds', HSBC (4 July 2016), https://www.gbm.hsbc.com/ /media/gbm/reports/insights/ social-bonds.pdf (accessed 20 April 2018).

19 See Tessa Wilkie, 'Social Bonds Busy Making More Friends', Global Capital (29 September 2015), https://www. globalcapital.com/article/tjjyspfc6s31/social-bonds-busy-making-more-friends (accessed 20 April 2018).

20 See, e.g., Damiano de Felice, 'Banks and Human Rights Due Diligence: A Critical Analysis of the Thun Group's Discussion Paper on the UN Guiding Principles on Business and Human Rights' (2015) 19 The International Journal of Human Rights 319, 330 ('The relationship between banks and human rights is under the spotlight ... Research on banks and human rights is also proliferating around the world.').

21 See Mary Dowell-Jones, 'Financial Institutions and Human Rights' (2013) 13 Human Rights Law Review 423, 429 ('This is the core of the challenge for the business and human rights agenda in the financial sector in light of the crisis to focus on defining principles and methodologies that are practically applicable to the complex array of products, processes and services that make up modern finance, using the UN Guiding Principles as the normative framework.'). 22 See Anita Ramasastry, 'Corporate Social Responsibility Versus Business and Human Rights: Bridging the Gap Between Responsibility and Accountability' (2015) 14 Journal of Human Rights 237, 249-50 (contrasting the objectives of corporate social responsibility [CSR] and business and human rights [BHR]).
} 
conceptual framework for evaluating human rights considerations in impact investing and applies this framework to the social bond market. Part V proposes reforms to current governance standards and practices in order to address their human rights shortcomings.

\section{From Sustainable Development to Sustainable Finance}

\section{A. Sustainable Development, Human Rights and Finance}

Famously articulated by the Brundtland Commission in 1987, the over-arching goal of sustainable development is 'to ensure that [humanity] meets the needs of the present without compromising the ability of future generations to meet their own needs' ${ }^{23}$ Sustainable development embraces the inter-related goals of achieving durable and equitable economic growth, preserving the natural environment, and maximizing social welfare. ${ }^{24}$ Businessoriented frameworks such as the 'Triple Bottom Line' apply sustainable development to the strategic decision-making and operational processes of firms. ${ }^{25}$

Prior to the SDGs, the Millennium Development Goals (MDGs) constituted the most significant global initiative on sustainable development. ${ }^{26}$ The MDGs included few definitive references to international human rights law, aside from exhortatory and nonbinding language concerning human rights in the name of democracy and good governance. ${ }^{27}$ Furthermore, the international human rights system did not engage with the MDGs. ${ }^{28}$ This resulted in numerous conflicts and gaps between specific goals of the MDGs and international human rights law. ${ }^{29}$ This disjuncture mirrors the struggle to incorporate human rights-based approaches into international economic development practice. $^{30}$

In contrast, various United Nations (UN) human rights organs, such as the Office of the United Nations High Commissioner for Human Rights (OHCHR), have engaged and contributed to the formulation and implementation of the SDGs. ${ }^{31}$ All 17 goals are

23 United Nations General Assembly, 'Report of the World Commission on Environment and Development: Our Common Future', A/42/427 (4 August 1987), annex, sec 1, para 27.

24 See Stephen K Park and Gerlinde Berger-Walliser, 'A Firm-Driven Approach to Global Governance and Sustainability' (2015) 52 American Business Law Journal 255, 270.

25 See John Elkington, Cannibals with Forks: The Triple Bottom Line of 21st Century Business (Gabriola, BC: New Society Publishers, 1998) 70, 96.

26 Ved P Nanda, 'The Journey from the Millennium Development Goals to the Sustainable Development Goals' (2016) 44 Denver Journal of Law and International Policy 389.

27 UN General Assembly, 'United Nations Millennium Declaration', A/RES/55/2 (8 September 2000), paras 24-25.

28 Philip Alston, 'Ships Passing in the Night: The Current State of the Human Rights and Development Debate seen through the Lens of the Millennium Development Goals' (2005) 27 Human Rights Quarterly 755, 760-61.

29 For example, the International Covenant on Economic, Social and Cultural Rights (ICESCR) provides that ' $[\mathrm{t}] \mathrm{he}$ States Parties to the present Covenant, recognizing the fundamental right of everyone to be free from hunger...', International Covenant on Economic, Social and Cultural Rights, 993 United Nations Treaty Series 3 (16 December 1966), art 11, whereas the corresponding commitment in the MDGs provides '[w]e resolve...[t]o halve, by the year 2015 , the proportion of the world's people whose income is less than one dollar a day and the proportion of people who suffer from hunger...', United Nations Millennium Declaration, note 27, para 19.

30 See Philip Alston and Mary Robinson, 'The Challenges of Ensuring the Mutuality of Human Rights and Development Endeavors' in Philip Alston and Mary Robinson (eds.), Human Rights and Development: Towards Mutual Reinforcement 3 (Oxford, 2005).

31 See, e.g., OHCHR, 'Human Rights and the 2030 Agenda for Sustainable Development', https://www.ohchr.org/ EN/Issues/MDG/Pages/The2030Agenda.aspx (accessed 20 April 2018) ('OHCHR has made a strong contribution to the integration of human rights throughout the process to define the SDGs and will seek to ensure that strategies and policies to implement the 2030 Agenda are human rights-based.'). 
undergirded by specific human rights derived from UN and International Labour Organization (ILO) instruments. ${ }^{32}$

Of particular note, the SDGs acknowledge the importance of identifying and leveraging private sources of financial capital to achieve the SDGs. Goal 17.3 provides for the mobilization of financial resources from multiple sources. ${ }^{33}$ Furthermore, Goal 17.17 calls on countries to encourage and promote multi-stakeholder partnerships, without making explicit references to finance. ${ }^{34}$ However, the SDGs do not expressly circumscribe or mandate the conduct of private parties in their capacity as sources of financial capital. ${ }^{35}$ The growing role and impact of the private sector in relation to traditionally public functions has been an increasingly vexing challenge in human rights. ${ }^{36}$ Under the Guiding Principles, a state continues to have an obligation to protect human rights even if the private actor is providing the public service. ${ }^{37}$ When the public service is essential to the fulfilment of a human right, the International Covenant on Economic, Social and Cultural Rights (ICESCR) stipulates that private providers be subject to 'public service obligations' that are universal, continuous, affordable, and of a certain quality. ${ }^{38}$

\section{B. Sustainable Finance and Impact Investing}

The concept of sustainable finance seeks to align the goals of sustainable development and the incentives of actors in the global financial system. ${ }^{39}$ A key component of sustainable finance is the rapidly growing awareness of pension funds, mutual funds, insurers and other institutional investors in sustainability and the SDGs. ${ }^{40}$ Socially responsible investing has entered the mainstream, ${ }^{41}$ and the language of sustainable

\footnotetext{
32 Among the specific human rights instruments are the ICESCR, the International Covenant on Civil and Political Rights (ICESCR), the Universal Declaration of Human Rights (UDHR), the Convention on the Elimination of All Forms of Discrimination against Women (CEDAW), the Convention on the Rights of the Child (CRC), the Convention on the Rights of Persons with Disabilities (CRPD), the Declaration on the Right to Development (DRtD), the Declaration on the Rights of Indigenous Peoples (UNDRIP), the International Convention on the Protection of the Rights of All Migrant Workers and Members of Their Families (ICRMW), and several ILO conventions. See OHCHR, Table on SDGs and Related Human Rights (untitled), http://www.ohchr.org/Documents/Issues/MDGs/Post2015/SDG_HR_Table.pdf (accessed 20 April 2018). See also Danish Institute for Human Rights, 'The Human Rights Guide to the Sustainable Development Goals', https://sdg.humanrights.dk/ (accessed 20 April 2018) (providing an interactive database).

332030 Agenda, note 1, 26, para 17.3.

34 Ibid, 27, para 17.17.

35 See Pogge and Sengupta, note 3, 585-86.

36 See Alston, note 28, 768.

37 Guiding Principles, note 5, Principle 5, Commentary.

38 See Committee on Economic, Social and Cultural Rights, 'General Comment No. 24 on State Obligations under the International Covenant on Economic, Social and Cultural Rights in the Context of Business Activities', E/C.12/GC/24 (adopted 23 June 2017), 7-8, para 21.

39 See United Nations Environment Programme, The Financial System We Need (October 2015), 17, https://wedocs. unep.org/bitstream/handle/20.500.11822/9862/-

The_Financial_System_We_Need_Aligning_the_Financial_System_with_Sustainable_Development-

2015The_Financial_System_We_Need_EN.pdf.pdf (accessed 20 April 2018).

40 See Avi Sharma, 'Who Leads in a G-Zero World? Multi-Nationals, Sustainable Development, and Corporate Social Responsibility in a Changing Global Order' (2015) 24 Washington International Law Journal 589, 607-8.

41 Gregory Unruh et al, 'Investing for a Sustainable Future', M.I.T. Sloan Management Review (11 May 2016) 1, 7 (noting that over 70 per cent of institutional investors consider sustainability as central to their investment decisions).
} 
development has become a tool to express social objectives and impact in the global financial markets. ${ }^{42}$

As a general matter, the commitment of institutional investors to human rights hinges on their potential financial impact on a given investment. ${ }^{43}$ They make investment decisions based on risk-return considerations, which include environmental, social and governance (ESG) issues. ${ }^{44}$ On the risk side, ESG risk encompasses a range of poor environmental, social and governance practices by companies that pose firm-specific operational risks, heighten market risk, or constitute systemic risks to the global financial system. ${ }^{45}$ Investors are increasingly aware of operational, reputational and legal risks associated with human rights and the positive correlation between a company's social performance and its operational performance. ${ }^{46}$ On the return side, socially responsible investing provides opportunities to improve financial returns (particularly over long time horizons) and meet growing client and employee demands for positive social impacts. ${ }^{47}$

The most prevalent means by which investors seek to address environmental and social objectives, such as human rights, is by 'screening out' investments in companies that fail to meet pre-defined standards. ${ }^{48}$ To achieve the SDGs, institutional investors will need to look beyond ESG screening. ${ }^{49}$ Impact investing represents the future of sustainable finance. ${ }^{50}$ In contrast to negative ESG screening, impact investing involves the active, intentional selection of investments in companies, organizations, projects or funds for the purpose of creating a positive social or environmental impact. ${ }^{51}$ In the past few years, institutional investors and other large financial firms have increasingly entered

42 See, e.g., 'SDGs are Becoming the Language for Investors when it comes to Assessing Impact', Environmental Finance (24 March 2017), https://www.environmental-finance.com/content/news/sdgs-are-becoming-the-languagefor-investors-when-it-comes-to-assessing-impact.html (accessed 20 April 2018); Alex Struc, 'Sustainable Development Goals: Common Goals, Our Approach, Your Impact' (Pimco, January 2017), https://www.pimco.com/en-us/insights/ viewpoints/viewpoints/sustainable-development-goals-common-goals-our-approach-your-impact (accessed 20 April 2018) (noting that '[i]nterviewees stated that they view the SDGs as a global declaration that investing in sustainable development is an investment opportunity for the private sector').

43 Benjamin J Richardson, 'Keeping Ethical Investment Ethical: Regulatory Issues for Investing for Sustainability' (2009) 87 Journal of Business Ethics 555.

44 African Development Bank et al, 'From Billions to Trillions: Transforming Development Finance - Post-2015 Financing for Development: Multilateral Development Finance', DC2015-0002 (2 April 2015) 12.

45 Virginia H. Ho, 'Risk-Related Activism: The Business Case for Monitoring Non-Financial Risk' (2016) 41 Journal of Corporation Law 629, 637-38.

46 See Pluess, Govan and Pelaez, note 9, 18. See also Allan Ferrell, Hao Liang and Luc Renneboog, 'Socially Responsible Firms' (2016) 122 Journal of Financial Economics 585 (finding that strongly managed firms are more likely to be socially responsible).

47 Pluess, Govan and Pelaez, note 9, 17-19.

48 Jennifer Goodman, Céline Louche, Katinka C Van Cranenburgh and Daniel Arenas, 'Social Shareholder Engagement: The Dynamics of Voice and Exit' (2014) 125 Journal of Business Ethics 193, 195. See also Benjamin J Richardson, 'Socially Responsible Investing for Sustainability: Overcoming Its Incomplete and Conflicting Rationales' (2013) 2 Transnational Environmental Law 311, 317 (defining complicity-based strategies for socially responsible investing).

49 See Edward J Waitzer and Douglas Sarro, 'Fiduciary Society Unleashed: The Road Ahead for the Financial Sector' (2014) 69 The Business Lawyer 1081, 1098 (calling for an integrative approach to investment that takes into account broader social, economic and environmental goals).

50 See Pluess, Govan and Pelaez, note 9, 21.

51 Rebecca Tekula and Archana Shah, 'Impact Investing: Funding Social Innovation' in Lehner (ed.), note 12, 125, 126. 
this market. ${ }^{52}$ Examples of impact investing include social impact bonds and quasiequity debt investments in social enterprises. ${ }^{53}$ However, the growth of impact investing as a means of achieving the SDGs is hindered by the paucity of scalable financial products. ${ }^{54}$ As a growing number of investors seek opportunities to generate social impact, there are not enough investment opportunities that meet their risk-return expectations, thereby limiting access to the enormous pools of capital managed by institutional investors. ${ }^{55}$ Accordingly, innovation is necessary to create new financial instruments and strategies that appeal to institutional investors while addressing the needs of sustainable development. ${ }^{56}$

\section{Social Bonds as an Impact Investing and Sustainable Development STRATEGY}

The social bond is an example of financial innovation in impact investing. The following discussion examines the legal, financial and operational characteristics of social bonds and their relationship to the principles of sustainable development.

\section{A. Socially Themed Bonds: Social Bonds and Sustainability Bonds}

Bonds are debt securities with which an issuer borrows money from investors in exchange for periodic payments of interest and repayment in full of the loan. ${ }^{57}$ A social bond is a type of bond that raises capital to finance projects with one or more social objectives. ${ }^{58}$ Social bonds are an offshoot of the larger and better established market for green bonds, which are dedicated to financing low-carbon, climate-resilient 'green' projects. ${ }^{59}$ Green bonds have risen to prominence as the risks of climate change and the investment needs of the Paris Agreement have garnered growing attention in the global capital markets. ${ }^{60}$ Sustainability bonds, a hybrid of social and green bonds, support both

52 Global Impact Investing Network, ‘2017 Annual Impact Investor Survey’ (May 2017) (GIIN 2017 Impact Investor Survey) 15, https://thegiin.org/assets/GIIN_AnnualImpactInvestorSurvey_2017_Web_Final.pdf (accessed 20 April 2018).

53 See Antony Bugg-Levine, Bruce Kogut and Nalin Kulatilaka, 'A New Approach to Funding Social Enterprises', Harvard Business Review (January-February 2012) 121-22.

54 Pluess, Govan and Pelaez, note 9, 29.

55 Global Impact Investing Network, note 52, 9.

56 See Georgia L Keohane, Capital and Common Good (New York: Columbia University Press, 2016) 3-4.

57 'What Is a Bond?', Wall Street Journal, https://guides.wsj.com/personal-finance/investing/what-is-a-bond (accessed 20 April 2018).

58 See International Finance Corporation, 'Social Bonds: Introduction and Impact Report' (IFC Social Bonds Report) (March 2017) 3.

59 See Organisation for Economic Cooperation and Development, 'Green Bonds: Mobilising the Debt Capital Markets for a Low-Carbon Transition' (OECD Green Bond Report) (December 2015), https://www.oecd.org/ environment/cc/Green\%20bonds\%20PP\%20[f3]\%20[lr].pdf (accessed 20 April 2018).

60 See Abby Ivory, Paul F Brown and David Chen, 'How Green Bonds Will Become Mainstream' Stanford Social Innovation Review (18 July 2016), https://ssir.org/articles/entry/how_green_bonds_will_become_mainstream (accessed 20 April 2018). 
social and green projects or projects that expressly address both social and environmental objectives. $^{61}$

Social bonds are defined by their use of proceeds. The defining characteristic of a social bond vis-à-vis a standard (or 'plain vanilla') bond is earmarking. Investors support a social project by purchasing a social bond whose proceeds are allocated (i.e., earmarked) to finance a social project set forth in the terms and conditions of the bond. ${ }^{62}$ This provides assurance to investors that the issuer will not use the funds for some other non-social purpose.

Social bonds are notable for their flexibility, simplicity and adaptability. The Social Bond Principles (SBPs), the leading investor-based standard in the social bond market, defines social bonds as 'any type of bond instrument where the proceeds will be exclusively applied to finance or re-finance in part or in full new and/or existing eligible Social Projects' ${ }^{63}$ Projects may be dedicated to improving, building and/or promoting utilities (e.g., electricity, gas, water), affordable housing, employment generation, food security, and socio-economic advancement and empowerment (e.g., health, education). ${ }^{64}$ Affordable housing and support for small and medium size enterprises (SMEs) have been the most frequent recipients of social bond proceeds. ${ }^{65}$ The social objective of a project must be for the benefit of a specific population, such as people living below the poverty line, excluded and/or marginalized populations, vulnerable groups, migrants and displaced persons, and under-educated and unemployed individuals. ${ }^{66}$ Any social objective that meets these broad criteria and is set forth in the use of proceeds of the social bond contract is permissible. The issuer has the discretion to determine what constitutes a successful outcome.

The structure of social bonds is simple. ${ }^{67}$ The fact that a social bond resembles a regular bond is an intrinsic part of its appeal to institutional investors. ${ }^{68}$ Investors are repaid in the same way as a corporate, municipal, sovereign or other plain vanilla bond. On the flip side, the investment downside of a given social bond is capped. ${ }^{69}$ As investors are only exposed to the credit risk of the issuer, they are not exposed to the risks

\footnotetext{
61 International Capital Markets Association, 'The Sustainability Bond Guidelines 2017' (2 June 2017), https://www. icmagroup.org/assets/documents/Regulatory/Green-Bonds/SustainabilityBondGuidelines-JUNE2017.pdf (accessed 20 April 2018).

62 Earmarking consists of funds, such as from a bond issuance, which are set aside to pay for a specific project or event. Investopedia, 'Earmarking', https://www.investopedia.com/terms/e/earmarking.asp (accessed 20 April 2018). In its most robust form, earmarking involves integration of the solicitation of financing, the sale of the financial instrument, the selection of the project, and the allocation of funds into a sub-account or a sub-portfolio prior to disbursement. International Finance Corporation, note 58, 6.

63 International Capital Markets Association, note 16, 1.

64 Ibid, 2-3.

65 Ross Lancaster, 'Social Bonds Show Good Growth by Following Green Bond Path', Global Capital (30 September 2016), https://www.globalcapital.com/article/zr06xn0v90f5/social-bonds-show-good-growth-by-following-greenbond-path (accessed 20 April 2018) (citing a study covering the period between 2014 and 2016).

66 International Capital Markets Association, note 16, 3.

67 Ana Demel, 'Second Thoughts on Social Impact Bonds' (2013) 9 NYU Journal of Law \& Business 503, 504-05, 509 (favourably contrasting green bonds to social impact bonds).

68 See Jon Hay, 'Fixed Income: Is Responsible Investing Becoming the Norm?' Global Capital (September 2015) 6 (noting growing interest among Principles for Responsible Investment [PRI] signatories in government and corporate bonds).

69 See George G Triantis and Ronald J Daniels, 'The Role of Debt in Interactive Corporate Governance' (1995) 83 California Law Review 1073, 1104-5.
} 
of a given project beyond the money paid to purchase the social bond. ${ }^{70}$ In the event that the issuer is unable to make interest payments or repay the principal on the bond, investors have direct recourse to the issuer. ${ }^{71}$

An issuer of a social bond may be a financial institution (such as a private commercial bank, a state-owned bank, or a multilateral development bank), a company, a non-profit organization, or a governmental entity. The prototype of the social bond market was created by the International Finance Facility for Immunisation (IFFIm), a partnership of ten donor countries. ${ }^{72}$ Starting in 2006, IFFIm has sought to leverage its donor pledges and its donor countries' strong credit ratings by issuing bonds. ${ }^{73}$ To date, social bond issuers have been predominantly public financial institutions with express development and/or social mandates. ${ }^{74}$ Early entrants in the social bond market include the Inter-American Development Bank's Education, Youth and Employment (EYE) Bond Program, ${ }^{75}$ the International Finance Corporation (IFC)'s Social Bond Program (consisting of its Banking on Women Bond and Inclusive Business Bond sub-programs), ${ }^{76}$ the Instituto de Crédito Oficial (ICO)'s Social Bond Program, ${ }^{77}$ and Dutch Development Bank FMO's Sustainability Bond Program. ${ }^{78}$

In the past two years, private banks and companies have begun issuing social bonds, signalling a fundamental shift in this market. Among the most notable issuers are Starbucks, ${ }^{79}$ Danone ${ }^{80}$ and various commercial banks such as Lloyds Bank, the largest retail bank in the United Kingdom. ${ }^{81}$ Social bonds are potentially attractive to private

70 See 'A Dull Shade of Green', The Economist (29 October 2011), https://www.economist.com/node/21534810 (accessed 20 April 2018).

71 Climate Bonds Initiative, 'Explaining Green Bonds', https://www.climatebonds.net/market/explaining-greenbonds (accessed 20 April 2018).

72 David Gartner, 'Innovative Financing and Sustainable Development: Lessons from Global Health' (2015) 24 Washington International Law Journal 495, 498-501.

73 Ibid. Through 2016, IFFIm raised US $\$ 5.7$ billion through bond issuances. International Finance Facility for Immunisation Company, 'Annual Report of the Trustees and Consolidated Financial Statements' (31 December 2015) 15, https://www.iffim.org/library/documents/trustees-reports/trustees-report-and-financial-statements-for-the-periodended-31-december-2016 (accessed 20 April 2018).

74 See Ben Edwards, 'Green Bonds Go Social', International Financing Review (April 2016) 14, https://edition. pagesuite-professional.co.uk//launch.aspx?eid=b00f8134-fc53-433b-acb8-5cb643837a79 (accessed 20 April 2018).

75 See Inter-American Development Bank, 'Fact Sheet, Education, Youth and Employment (EYE) Bond' (IDB EYE Bond Fact Sheet), https://www.iadb.org/document.cfm?id=39047836 (accessed 20 April 2018).

76 See International Finance Corporation, note 58.

77 See Instituto de Crédito Oficial, 'ICO - Social Bonds', https://www.ico.es/web/ico_en/ico-social-bonds (accessed 20 April 2018). ICO (Instituto de Crédito Oficial) is a state-owned bank under Spain's Ministry of Economic Affairs, Industry and Competitiveness. See Instituto de Crédito Oficial, 'What is ICO?', https://www.ico.es/web/ico_en/whatico-is (accessed 20 April 2018).

78 FMO is the development bank of the Netherlands, and its sustainability bond includes inclusive finance (principally microfinance) as a category for its use of proceeds. See Sustainalytics, 'FMO Sustainability Bond - Framework Summary and Second Opinion' (April 2015), 2-3, https://www.sustainalytics.com/sites/default/files/ fmo_sustainability_bond_framework_review_and_opinion.pdf (accessed 20 April 2018).

79 Starbucks, Press Release, 'Starbucks Issues the First U.S. Corporate Sustainability Bond' (16 May 2016), https:// news.starbucks.com/press-releases/starbucks-issues-the-first-u.s.-corporate-sustainability-bond (accessed 20 April 2018).

80 Danone's social bond was the first issued by a multinational corporation under the Social Bond Principles. Danone, Press Release, 'Danone Successfully Issues a Pioneer $€ 300 \mathrm{~m}$ Social Bond Continuing to Invest for Sustainable Value for All (19 March 2018), https://danone-danonecom-prod.s3.amazonaws.com/ Danone_Press_Release_Social_Bond_EN.pdf (accessed 20 April 2018).

81 Lloyds Bank, Press Release, 'Lloyds Bank Completes Allocation of its Inaugural $£ 250$ Million Environmental, Social and Governance Bond' (24 March 2015), https://www.lloydsbankinggroup.com/globalassets/documents/media/ press-releases/lloyds-bank/2015/15.03.24-esg-bond-update-final.pdf (accessed 20 April 2018). 
banks and companies in part due to their branding value. As institutional investors show greater interest in social responsibility, social bonds enable companies to signal their commitment to sustainability. ${ }^{82}$ In doing so, companies can attract new investors to their borrowing programmes and diversify their sources of capital. ${ }^{83}$

\section{B. Social Bonds and Sustainable Development}

Social bonds address the principles of sustainable development both explicitly and implicitly. In explicit terms, social bonds are marketed to investors as a means to specifically contribute to the fulfilment of the SDGs. ${ }^{84}$ A pioneering social bond issued by the World Bank in 2017 uses the SDGs as the basis for determining both the financial and social return to investors. ${ }^{85}$ This social bond links returns to the stock performance of a basket of companies in the Solactive Sustainable Development Goals World Index. ${ }^{86}$ In turn, as part of its 'SDGs Everyone' initiative, the World Bank commits to use the proceeds to support the financing of projects aligned with the SDGs. ${ }^{87}$

Implicit references to the SDGs abound in the social bond market. Numerous social bonds focus on providing opportunities for human capital development. A pioneering social bond issued by the ICO is used to provide affordable financing to small, medium and micro-enterprises. ${ }^{88}$ Loans are targeted towards employment creation and retention in pre-specified economically under-performing regions of Spain. ${ }^{89}$ This aligns with SDG 8, Decent Work and Economic Growth, and its emphasis on inclusive economic growth and full and productive employment. ${ }^{90}$ Also consistent with SDG 8 is Starbucks' sustainability bond, which provides direct support to farmers participating in the company's sustainable sourcing programmes. ${ }^{91}$ Another focus area is infrastructure investment, often integrated into sustainability bonds that finance both social and

82 See Sophia Grene, 'Lloyds Bank Goes Green and Patriotic', Financial Times (3 August 2014), https://www.ft.com/ content/4c1f1240-1277-11e4-a581-00144feabdc0 (accessed 20 April 2018) ('[Lloyds' ESG bond] makes it suitable for the growing number of asset managers with targets for allocations to responsible investment, but who are unwilling to see higher risk or lower return as a trade-off.').

83 Wilkie, note 19.

84 See International Finance Corporation, 'Social Bond Program', 7, https://www.ifc.org/wps/wcm/connect/ 54dd263d-1097-42f0-8ce0-16e13b762c22/IFC+Social+Bond+Program+Presentation+final_Oct2016.pdf? MOD=AJPERES (accessed 20 April 2018).

85 Helen Bartholomew, 'World Bank Issues First UN Sustainable Development Bond', Reuters (9 March 2017), https://www.reuters.com/article/world-bank-issues-first-un-sustainable-d-idUSL5N1GL61E (accessed 20 April 2018).

86 See World Bank, Press Release, 'World Bank Launches Financial Instrument to Expand Funding for Sustainable Development Goals' (9 March 2017), https://treasury.worldbank.org/cmd/htm/World-Bank-Launches-FinancialInstrument-to-Expand-Funding-for-Sustainable-Development.html (accessed 20 April 2018).

87 Ibid.

88 Sustainalytics, 'The Instituto de Crédito Official Social Bond - Framework Overview and Second-Party Opinion by Sustainalytics' (ICO Social Bond Second Opinion) (2014), 3, https://www.ico.es/documents/19/69769/SECOND +OPINION+ICO+Social+Bond+Framework.pdf/44cfbcad-7f67-4528-ac65-e9eefce8d070 (accessed 20 April 2018).

89 Ibid.

90 See 2030 Agenda, note 1, 26, 19, para 8.3 ('Promote development-oriented policies that support productive activities, decent job creation, entrepreneurship, creativity and innovation, and encourage the formalization and growth of micro-, small- and medium-sized enterprises, including through access to financial services'); see also Sustainalytics, 'Sustainable Momentum - 2015 Sustainability Report' 24, marketing.sustainalytics.com/acton/attachment/5105/f07c0/0/-//-///SustainableMomentum-SustainabilityReport-2015.pdf (accessed 20 April 2018).

91 Sustainalytics, 'Starbucks Corporation Sustainability Bond - Framework Overview and Second Opinion by Sustainalytics' (6 March 2017) 4-5, https://www.sustainalytics.com/wp-content/uploads/2017/03/ Starbucks_Sustainability_Bond_English.final_.pdf (accessed 20 April 2018). 
environmental projects. ${ }^{92}$ Finally, social bonds are used to finance basic social services, with a focus on providing capital to serve marginalized populations. To cite one example, Lloyds Bank's ESG Bond aims to enhance the bank's SME lending by supporting loans to UK-based, small-scale renewable energy and healthcare providers in the most poverty-stricken parts of the UK. ${ }^{93}$ This aligns with SDG 11, Sustainable Cities and Communities and its emphasis on urban residential services ${ }^{94}$ and SDG 3, Good Health and Well-Being, and its goal of broadening access to healthcare. ${ }^{95}$

\section{Human Rights and Impact Investing: An Analysis of the Social Bond MARKET}

Human rights considerations have been under-studied in relation to impact investing. To address this, the following discussion suggests three factors to evaluate impact investing instruments and strategies and applies them to the social bond market.

\section{A. A Framework for Evaluating Human Rights Accountability in Impact Investing}

Growing investor interest in sustainability and the emergence of social bonds highlight the lack of specific authoritative guidance on how to address human rights in the context of impact investing. While the Guiding Principles do not provide guidance in any specific sectoral context, ${ }^{96}$ institutional investors and other financial market participants have explored the application of human rights to other areas of finance. The Thun Group, an informal group of global financial institutions, has deliberated on the application of the Guiding Principles to banking policies and practices. ${ }^{97}$ The Equator Principles, a voluntary initiative that addresses environmental and social risk in project finance, expressly recognizes the corporate responsibility to respect human rights under the Guiding Principles. ${ }^{98}$ Most recently, the Organisation for Economic Cooperation and Development (OECD) issued guidance on the human rights obligations of institutional investors under the OECD Guidelines for Multinational Enterprises. ${ }^{99}$ Along with the

\footnotetext{
92 Many green bonds focus on low carbon infrastructure. See Organisation for Economic Cooperation and Development, note 59, 2-3. Green bond financing directly aligns with SDGs 6 (Clean Water and Sanitation), 7 (Affordable and Clean Energy), 11 (Sustainable Cities and Communities), 12 (Responsible Consumption and Production), 13 (Climate Change), 14 (Life below Water), and 15 (Life on Land).

93 Sustainalytics, 'Lloyds Bank - Helping Britain Proper ESG Bond Framework' (30 June 2014) 8, https://www. sustainalytics.com/sites/default/files/20140630_lloyds_bank_hbp_bond_framework_final.pdf $\quad$ (accessed 20 April 2018).

94 See 2030 Agenda, note 1, 26, 22, para 11.6 ('By 2030, reduce the adverse per capita environmental impact of cities, including by paying special attention to air quality and municipal and other waste management').

95 See ibid, para 3.8 ('Achieve universal health coverage, including financial risk protection, access to quality essential health-care services and access to safe, effective, quality and affordable essential medicines and vaccines for all').

96 Dowell-Jones, note 21, 429.

97 See UBS, 'Thun Group', https://www.ubs.com/global/en/about_ubs/ubs-and-society/how-we-do-business/ sustainability/thun-group.html (accessed 20 April 2018). See also de Felice, note 20, 325-30 (identifying and analysing shortcomings in the Thun Group's approach to the human rights obligations of banks).

98 See The Equator Principles III (June 2013), 2, https://equator-principles.com./wp-content/uploads/2017/03/ equator_principles_III.pdf (accessed 20 April 2018).

99 Organisation for Economic Cooperation and Development, 'Responsible Business Conduct for Institutional Investors: Key Considerations for Due Diligence under the OECD Guidelines for Multinational Enterprises' (OECD
} 
Guiding Principles, these standards and declarations serve as templates for potential approaches to addressing human rights in impact investing.

Impact investing differs from banking, project finance and other types of finance. It is predominantly governed by various forms of private legal ordering. At the international level, the UN-supported Principles for Responsible Investment (PRI) commits members to address ESG issues based on six principles. ${ }^{100}$ The Global Impact Investing Network (GIIN), a global industry association, has addressed the role of the SDGs in impact investing. ${ }^{101}$ This stands in contrast to banking, which is highly regulated by governments at the national and sub-national levels, and project finance, which heavily draws on the social and environmental standards of the International Finance Corporation and other multilateral and governmental development agencies. ${ }^{102}$

Governments struggle to regulate many environmental and social impacts attributable to global commercial activity, including impacts that directly implicate human rights. ${ }^{103}$ Private governance helps fill this governance gap. ${ }^{104}$ The legal authority of private governance is not derived from governments. Rather, private governance regimes are composed of groups of firms that agree to regulate themselves. ${ }^{105}$ Instead of centralized lawmaking and enforcement, private governance generally relies on decentralized processes based on negotiation and dialogue to create standards, which are enforced through investigation and disclosure. ${ }^{106}$ Market-based mechanisms assess, measure, audit, label and otherwise facilitate communication of the social and environmental conduct of companies. ${ }^{107}$

With these distinguishing characteristics in mind, there are three factors that impact investors should take into account to ensure that their investments align with human rights: investor assessment, external assurance, and impact-maximizing leverage. With

(F'note continued)

Institutional Investor Guidance) (28 March 2017), https://mneguidelines.oecd.org/RBC-for-Institutional-Investors.pdf (accessed 20 April 2018).

100 Principles for Responsible Investment, 'The Six Principles', https://www.unpri.org/about/the-six-principles (accessed 20 April 2018).

101 Global Impact Investing Network, 'Achieving the Sustainable Development Goals: The Role of Impact Investing' (September 2016), https://thegiin.org/assets/GIIN_Impact\%20InvestingSDGs_Finalprofiles_webfile.pdf (accessed 20 April 2018).

102 See John M Conley and Cynthia A Williams, 'Global Banks as Global Sustainability Regulators?: The Equator Principles' (2011) 33 Law and Policy 542, 543-44.

103 See, e.g., Andreas G Scherer, Guido Palazzo and Dorotheé Baumann, 'Global Rules and Private Actors: Toward A New Role of The Transnational Corporation In Global Governance' (2006) 16 Business Ethics Quarterly 505, 512 ('... economic actors undermine the internal sovereignty of nation states, namely the state's ability to independently set rules and limit or regulate domestic private activities within its jurisdiction').

104 David Vogel, The Market for Virtue: The Potential and Limits of Corporate Social Responsibility (Washington, DC: Brookings Institution Press, 2005) 9 ('Civil regulation represents an effort to fill the governance gap between the law and the market.').

105 Kenneth W Abbott and Duncan Snidal, 'Strengthening International Regulation Through Transnational New Governance: Overcoming the Orchestration Deficit' (2009) 42 Vanderbilt Journal of Transnational Law 501, $520-33$. A growing number of multi-stakeholder initiatives (MSIs) include corporations, civil society organizations and other actors such as governments and unions. Sandra Waddock, 'Building a New Institutional Infrastructure for Corporate Responsibility' (2008) 22 Academy of Management Perspectives 87, 97-99.

106 John J Kirton and Michael J Trebilcock, 'Introduction: Hard Choices and Soft Law in Sustainable Governance' in John J Kirton and Michael J Trebilcock (eds.), Hard Choices, Soft Law: Voluntary Standards in Global Trade, Environment and Social Governance (London: Routledge, 2004) 3, 22-23.

107 Dirk U Gilbert, Andreas Rasche and Sandra Waddock, 'Accountability in the Global Economy: The Emergence of International Accountability Standards' (2011) 21 Business Ethics Quarterly 23, 24. 
the Guiding Principles as its conceptual foundation, this three-part framework accounts for the unique conditions of impact investing and capacity of institutional investors.

\section{Investor Assessment}

For impact investors, a first order consideration is to identify and assess how human rights issues are implicated by the projects and companies in which they invest. This requires that investors conduct human rights due diligence, a core component of the Guiding Principles. ${ }^{108}$ The first step in human rights due diligence is identification and assessment of actual or potential human rights impacts. ${ }^{109}$ Consistent with the concept of human rights due diligence, the OECD's definition of responsible business conduct risk refers to adverse impacts on society and the environment, rather than risks to the firm. ${ }^{110}$ Investors should conduct human rights due diligence prior to deciding whether or not to invest and whenever they have reason to believe that there has been a material change in the operations of funded projects or companies. ${ }^{111}$ In order for investors to be able to assess human rights impacts, they must be able to analyse the outcomes of their investments. ${ }^{112}$ In the investor-investee relationship, human rights impacts may arise from the specific project being funded as well as in the context of the general activities of the company executing the project. This warrants investor assessment at both the project level (i.e., the outcome of a specific financing) and the company level (i.e., the human rights performance of the company administering a given project). ${ }^{113}$

Investor assessment should incorporate human rights in procedural terms as well. Public transparency and civil society participation are particularly important in privately governed markets in order to ensure democratic legitimacy. ${ }^{114}$ Rights holders should be involved in the development and implementation of impact assessment as the decisions resulting therefrom affect them. ${ }^{115}$ Reflecting this principle, the Equator Principles require project finance lenders to conduct consultation and participation processes with affected communities. ${ }^{116}$ In impact investing, investor assessment

\footnotetext{
108 Human rights due diligence is a process 'to identify, prevent, mitigate and account for how they address their impacts on human rights', Guiding Principles, note 5, Principle 15(b). This process includes 'assessing actual and potential human rights impacts, integrating and acting upon the findings, tracking responses, and communicating how impacts are addressed'. Ibid, Principle 17.

109 Ibid, Principle 18. See also Robert McCorquodale, Lise Smit, Stuart Neely and Robin Brooks, 'Human Rights Due Diligence in Law and Practice: Good Practices and Challenges for Business Enterprises' (2017) 2:2 Business and Human Rights Journal 195, 205.

110 Organisation for Economic Cooperation and Development, note 99, 11. See also McCorquodale et al, note 109, 199-200 (distinguishing between business management due diligence and human rights due diligence).

111 See Guiding Principles, note 5, Principle 18, Commentary (noting the need for assessment of human rights impacts at regular intervals).

112 See Institute for Human Rights and Business, 'State of Play: Business and the Sustainable Development Goals: Mind the Gap - Challenges for Implementation' (September 2015) 53, https://www.ihrb.org/pdf/state-of-play/ Business-and-the-SDGs.pdf (accessed 20 April 2018).

113 See de Felice, note 20, 324 (criticizing the Thun Group's position on distinguishing human rights due diligence for general versus specific purpose financing).

114 See Sébastien Mena and Guido Palazzo, 'Input and Output Legitimacy of Multi-Stakeholder Initiatives' (2012) 22 Business Ethics Quarterly 527, 537-41 (identifying inclusion, procedural fairness, consensual orientation, and transparency as criteria for measuring the input legitimacy of MSIs).

115 Nora Götzmann, 'Human Rights Impact Assessment of Business Activities: Key Criteria for Establishing a Meaningful Practice' (2017) 2:1 Business and Human Rights Journal 87, 99 (arguing for the participation and inclusion of affected parties).

116 See The Equator Principles III, note 98, 7-8.
} 
should seek and incorporate input from stakeholders, particularly individuals affected by a financed project. ${ }^{117}$ Companies that receive financing should be required to continuously engage with investors and stakeholders on their human rights policies, practices and impacts. ${ }^{118}$ Investors should also disclose the policies and practices that guide their assessments of human rights impacts, as well as the results of their assessments. $^{119}$

\section{External Assurance}

Investor assessment in the global capital markets faces unique informational barriers due to the attenuated nature of institutional investors' relationships with the companies and projects in their portfolios. Many institutional investors are unable to effectively assess human rights risk and measure and verify positive human rights outcomes. ${ }^{120}$ The inconsistency, incompatibility and incompleteness of indicators impede rights-based accountability. ${ }^{121}$ Furthermore, many human rights impacts are often only evident in the long term, which hampers the ability of investors to determine when and how to balance short-term financial considerations and long-term human rights factors. ${ }^{122}$

These informational deficits can be addressed in part through mandatory disclosure of impacts. Over the past several decades, disclosure of social impacts has emerged as a key regulatory strategy. ${ }^{123}$ Consistent with this paradigm, the Guiding Principles incorporate reporting as an element of the corporate responsibility to protect. ${ }^{124}$ Under the Guiding Principles, human rights reporting must become institutionalized within the firm. ${ }^{125}$ Impact investors should seek any available means to encourage, incentivize, or require the companies, organizations, projects or funds in which they invest to collect and report on their human rights impacts. ${ }^{126}$

\footnotetext{
117 See Götzmann, note 115, 99.
}

118 See Organisation for Economic Cooperation and Development, note 99, 16 (defining due diligence as an 'ongoing, proactive and reactive, and process-oriented activity').

119 See Götzmann, note 115, 101, 105.

120 O'Connor and Labowitz, note 13, 18-22.

121 See Benjamin M Meier and Yuna Kim, 'Human Rights Accountability through Treaty Bodies: Examining Human Rights Treaty Monitoring for Water and Sanitation' (2015) 26 Duke Journal of Comparative \& International Law 142, 221 (analysing water and sanitation reporting under the ICESCR). Even development banks such as the World Bank struggle to ensure that the companies that they finance identify, analyse, and report human rights impacts. See Jessica Evans, 'The Record of International Financial Institutions on Business and Human Rights' (2016) 1:2 Business and Human Rights Journal 327, 327-28.

122 Dowell-Jones, note 21, 446-47. See also UN System Task Team on the Post-2015 UN Development Agenda, Working Group on 'Financing for Sustainable Development', 'Executive Summary' (UN System Task Team Executive Summary) 6, https://sustainabledevelopment.un.org/content/documents/2091Executive\%20Summary-UNTT\%20WG \%20on\%20SDF.pdf (accessed 20 April 2018) (noting the negative impact of misaligned and short-term incentives on the willingness of institutional investors to support sustainable development).

123 See David Hess, 'The Three Pillars of Corporate Social Reporting as New Governance Regulation: Disclosure, Dialogue, and Development' (2008) 18 Business Ethics Quarterly 447, 454-55.

124 Guiding Principles, note 5, Principle 21, Commentary ('Communication can take a variety of forms, including inperson meetings, online dialogues, consultation with affected stakeholders, and formal public reports.').

125 Ibid. See also John Gerard Ruggie, Just Business: Multinational Corporations and Human Rights (New York: W. W. Norton, 2013) 99 ('To discharge the responsibility to respect human rights requires that companies develop the institutional capacity to know and show that they do not infringe on others' rights.').

126 See Organisation for Economic Cooperation and Development, note 99, 29 (recommending that investors participate in industry-based disclosure initiatives as part of individual and collective efforts to obtain more information from investee companies). 
However, the quality and veracity of environmental and social disclosure is often doubted due to the control that companies exercise over this information. ${ }^{127}$ To enhance the credibility of this information, companies increasingly hire outside parties to independently review and verify a company's social and environmental performance. ${ }^{128}$ External assurance includes certification and independent auditing. ${ }^{129}$ These measures prevent whitewashing by subjecting companies to review of their policies and operations. ${ }^{130}$ Institutional investors, in particular, increasingly demand that the firms in which they invest subject their environmental and social information to external assurance. $^{131}$

Accordingly, investor assessment should be coupled with external assurance. However, external assurance should not be a precondition to taking action to address adverse human rights impacts. ${ }^{132}$ Consistent with the Guiding Principles, external assurance should be integrated, to the extent possible, in the investor's ongoing tracking of human rights impacts. ${ }^{133}$

\section{Impact-Maximizing Leverage}

Historically, institutional investors have been reluctant to actively engage with companies on human rights. ${ }^{134}$ As financial intermediaries, institutional investors invest assets on behalf of their clients to whom they owe fiduciary duties of loyalty, obedience and care. ${ }^{135}$ With few exceptions worldwide, the legal scope and content of these investor-based fiduciary duties with respect to human rights are weak and ambiguous. ${ }^{136}$

Human rights due diligence, as applied to institutional investors, seeks to counter this passivity. Once an investor has identified actual or potential human rights impacts, it should take appropriate action to prevent and mitigate them. ${ }^{137}$ This entails that the investor assesses its relationship to an adverse impact and determines its leverage over the entity concerned. ${ }^{138}$ With the Guiding Principles as its foundation, the OECD's

\footnotetext{
127 S Prakash Sethi, Terrence F Martell and Mert Demir, 'Enhancing the Role and Effectiveness of Corporate Social Responsibility (CSR) Reports: The Missing Element of Content Verification and Integrity Assurance' (2017) 144 Journal of Business Ethics 59, 61.

128 Ibid, 62.

129 Waddock, note 105, 91.

130 See Matthew Potoski and Aseem Prakash, 'Green Clubs and Voluntary Governance: ISO 14001 and Firms' Regulatory Compliance' (2005) 49 American Journal of Political Science 235, 246 (noting that external audits of ISO 14001 compliance prevent whitewashing).

131 Margaret M Blair, Cynthia A Williams and Li-Wen Lin, 'The New Role for Assurance Services in Global Commerce' (2008) 33 Journal of Corporation Law 325, 345.

132 See Organisation for Economic Cooperation and Development, note 99, 29 ('[I]nformation or claims about RBC risk or impacts does not have to be completely verified in order to trigger further investigation and closer engagement').

133 See Guiding Principles, note 5, Principle 20.

134 Dowell-Jones, note 21, 449. See also John M Conley and Cynthia A Williams, 'Engage, Embed, and Embellish: Theory Versus Practice in the Corporate Social Responsibility Movement' (2005) 31 Journal of Corporation Law 1, 21-23 (recounting and analysing sharply divergent views among institutional investors).

135 See Waitzer and Sarro, note 49, 1090.

136 Benjamin J Richardson and Wes Cragg, 'Being Virtuous and Prosperous: SRI's Conflicting Goals' (2010) 92 Journal of Business Ethics 21, 32-33.

137 Guiding Principles, note 5, Principle 19.

138 Ibid, Principle 19(b).
} 
guidance to institutional investors suggests a variety of ways that investors may exercise leverage over companies in their portfolios. If the investor owns equity stock in a corporation, it can exercise its governance rights to elect members of the board of directors. ${ }^{139}$ Investors that hold debt or other types of non-equity assets can also exercise leverage through engagement. ${ }^{140}$ However, if leverage is infeasible or ineffective, the investor may divest or screen out assets of the company. ${ }^{141}$

In the context of impact investing, the use of leverage should take into account its defining objective of generating positive social impact. Impact investing is premised on the concept of additionality - i.e., the production of beneficial social and environmental outcomes beyond what would otherwise have occurred if the capital had been deployed in some other way. ${ }^{142}$ In other words, the rationale for a given impact investment can be attributed to the fulfilment of human rights, such as those embedded in the SDGs.

The concept of additionality suggests two general considerations for impact investors. First, impact investors should avoid exit whenever possible in order to leverage their special relationships with companies and stakeholders. Impact investors should ensure that their capital investments fulfil human rights to the maximum possible extent (including social and economic rights). ${ }^{143}$ Relationship-based leverage, as defined by Stepan Wood, may be particularly relevant to impact investors. ${ }^{144}$ An investor's responsibility to exercise leverage may be established by a specific relationship with a given funded company as well as by the investor's general relationships in a given sector through its activities, products and services. ${ }^{145}$ Second, impact investors should be vigilant of adverse impacts embedded in projects that provide additionality. For example, a social bond that finances the construction of affordable housing should be undertaken in a manner that respects indigenous rights and addresses gender equality to the extent possible. ${ }^{146}$ This due consideration of positive human rights impacts does not relieve investors from their obligation to address adverse ones. ${ }^{147}$

\footnotetext{
139 Organisation for Economic Cooperation and Development, note 99, 32; see also Richardson and Peihani, note 11,433 .

140 Organisation for Economic Cooperation and Development, note 99, 31-33 (listing types of engagement strategies). Equity-based impact investing is prevalent in venture philanthropy and other impact investment strategies that employ venture capital or private equity models. See Tamaki Onishi, 'Institutional Analysis of Venture Philanthropy' in Lehner (ed.), note 12, 342, 354.

141 Organisation for Economic Cooperation and Development, note 99, 33.

142 Brest and Born, note 12, 25.

143 See Florian Wettstein, 'CSR and the Debate on Business and Human Rights: Bridging the Great Divide' (2012) 22 Business Ethics Quarterly 739, 757-59. This is consistent with approaches to human rights due diligence that take into account a company's positive human rights impacts as well as its adverse impacts. See Götzmann, note 115, 98.

144 Stepan Wood, 'The Case for Leverage-Based Corporate Human Rights Responsibility' (2012) 22 Business Ethics Quarterly 63, 64 ('Leverage-based responsibility... arises from an organization's ability to influence the actions of other actors through its relationships, regardless of whether the impacts of those other actors' actions can be traced to the organization.').

145 See ibid, 83-85 (defining the basis for morally significant connections).

146 The problem of adverse collateral impacts has arisen in green bond financed projects. See Banktrack, 'Open Letter on the 2015 Update of the Green Bond Principles' (30 April 2015) 2, https://www.banktrack.org/ems_files/download/ 150430_open_letter_to_green_bond_principles_pdf/150430_open_letter_to_green_bond_principles.pdf (accessed 20 April 2018).

147 Götzmann, note $115,98$.
} 


\section{B. Analysing the Social Bond Market}

These three factors can be applied to the social bond market to identify and evaluate its standards and practices from a human rights perspective.

While government regulators in China and India have issued guidelines for green bonds and the European Commission announced in March 2018 its intent to create standards and labels for green financial products, none of these public regulatory frameworks expressly addresses social bonds. ${ }^{148}$ Instead, the social bond market is largely governed by private governance standards, certification schemes and voluntary external assurance. The Social Bond Principles are the predominant global private standard. ${ }^{149}$ The SBPs consist of four core components: (i) use of proceeds, (ii) process for project evaluation and selection, (iii) management of proceeds, and (iv) reporting. ${ }^{150}$ These components define methods and processes for issuers to implement in their operations. ${ }^{151}$ While the SBPs are intended to aid issuers, investors and underwriters, ${ }^{152}$ issuers are primarily responsible for adhering to their guidelines. ${ }^{153}$ The SBPs' lack of prescriptiveness is a fundamental feature of the social bond market. ${ }^{154}$ Leading public issuers, such as IFC, expressly align their social bond programmes to the SBPs. ${ }^{155}$ For these reasons, an examination of the social bond market at this stage in its development should start with the SBPs. For this purpose, the SBPs can be assessed under the threepart framework outlined in Part IV (A) above. In accordance with this framework, the assessment that follows focuses on the conduct of investors, in contrast to the SBPs' issuer-based focus.

\footnotetext{
148 See Stephen K Park, 'Investors as Regulators: Green Bonds and the Governance Challenges of the Sustainable Finance Revolution' (2018) 54 Stanford Journal of International Law 1, 35-36; European Commission, 'Action Plan: Financing Sustainable Growth', COM(2018) 97 final (8 March 2018) 4-5.

149 The SBPs are modelled on the Green Bond Principles in the parallel green bond market. See International Capital Market Association, Press Release, 'Green Bond Principles Evolve to Encourage New Categories of Issuers and Embrace Social \& Sustainability Bond Market Participants' (14 June 2017), https://www.icmagroup.org/assets/ documents/Regulatory/Green-Bonds/Green,-Social-and-Sustainability-Bonds-Press-release.pdf（accessed 20 April 2018).

150 International Capital Markets Association, note 16, 2-3.

151 See Gilbert, Rasche and Waddock, note 107, 29 (defining process standards).

152 According to the SBPs:

[The SBPs] provide issuers with guidance on the key components involved in launching a credible Social Bond; they aid investors by promoting availability of information necessary to evaluate the positive impact of their Social Bond investments; and they assist underwriters by moving the market towards expected disclosures that will facilitate transactions.

International Capital Markets Association, note 16, 2.

153 See ibid ('The SBP recommend a clear process and disclosure for issuers, which investors, banks, investment banks, underwriters, placement agents and others may use to understand the characteristics of any given Social Bond.'). 154 The SBPs' disclaimer makes clear their voluntary, non-binding nature:

The Social Bond Principles are voluntary process guidelines that neither constitute an offer to purchase or sell securities nor constitute specific advice of whatever form (tax, legal, environmental, accounting or regulatory) in respect of Social Bonds or any other securities. The Social Bond Principles do not create any rights in, or liability to, any person, public or private. Issuers adopt and implement the Social Bond Principles voluntarily and independently, without reliance on or recourse to the Social Bond Principles, and are solely responsible for the decision to issue Social Bonds. Underwriters of Social Bonds are not responsible if issuers do not comply with their commitments to Social Bonds and the use of the resulting net proceeds. If there is a conflict between any applicable laws, statutes and regulations and the guidelines set forth in the Social Bond Principles, the relevant local laws, statutes and regulations shall prevail. International Capital Markets Association, note 16, 5 (emphasis added). 


\section{Investor Assessment}

Under the SBPs, issuers are encouraged to engage in due diligence on social risks associated with projects. Specifically, issuers must communicate to investors the specific social objectives, the process for the selection of projects, and eligibility criteria, including criteria for excluding projects that pose material social and environmental risks. ${ }^{156}$ Due diligence on social risks under the SBPs superficially resembles human rights due diligence. However, by not expressly referencing human rights, the SBPs do not distinguish between social risk (faced by the investor) and human rights risk (faced by rights holders). ${ }^{157}$ Moreover, the SBPs do not provide guidance on how an issuer or an investor should assess and respond to trade-offs between one kind of social risk vis-à-vis other social risks or between a certain level of social risk and financial returns from the project. ${ }^{158}$

In addition, the SBPs encourage issuers to communicate the social impact of projects. ${ }^{159}$ Under the SBPs, transparency is the primary means by which investors and other stakeholders hold issuers to account. ${ }^{160}$ However, the SBPs' lack of rules or guidance perpetuates the struggle of investors, regulators and other stakeholders to assess the social impact of social bonds, let alone consider human rights impacts. ${ }^{161}$

The SBPs expressly state as their over-arching mission the goal of issuers, investors and other market participants to expand the green bond market through private standards. ${ }^{162}$ Stakeholders are passive beneficiaries of the process standards established by the SBPs. ${ }^{163}$ An Executive Committee is responsible for the process and content of the SBPs. ${ }^{164}$ This committee consists solely of investors, issuers and underwriters. ${ }^{165}$ The Social Bond Working Group, which serves in an advisory capacity, includes development banks and socially responsible investors among its members. ${ }^{166}$

156 International Capital Markets Association, note 16, 3 (defining guidelines for process for project evaluation and selection).

157 Björn Fasterling, 'Human Rights Due Diligence as Risk Management: Social Risk Versus Human Rights Risk' (2017) 2:2 Business and Human Rights Journal 225, 230-31.

158 See ibid, 238-40 (examining problems associated with commensurability and human rights risk).

159 International Capital Markets Association, note 16, 3 ('Transparency is of particular value in communicating the expected impact of projects.').

160 Ibid ('[The SBPs] emphasise the required transparency, accuracy and integrity of information that will be disclosed and reported by issuers to stakeholders.').

161 See Wilkie, note 19 (noting how the diversity of loans financed by social bonds render it difficult to standardize reporting and accurately assess social impact for each project).

162 International Capital Markets Association, note 16, 2 ('[The SBPs] are intended for broad use by the variety of actors participating in the market and are designed to provide the information needed to increase capital allocation to social projects without any single arbiter.').

163 See ibid, 2-3.

164 See International Capital Markets Association, The Green Bond Principles and the Social Bond Principles, Governance Framework (14 June 2017), sec 3.3.2, https://www.icmagroup.org/Regulatory-Policy-and-Market-Practice/ green-social-and-sustainability-bonds/governance-framework (accessed 20 April 2018) ('[The Executive Committee] 1) appoints and oversees the Secretariat; 2) approves formal Principles communications; 3) votes on amendments to the Principles; and, 4) can propose and validate issue-specific working groups including Members and Observers.').

165 International Capital Markets Association, 'Executive Committee and Working Groups', https://www.icmagroup. org/Regulatory-Policy-and-Market-Practice/green-social-and-sustainability-bonds/executive-committee-and-workinggroups/ (accessed 20 April 2018).

166 GBP Executive Committee 2016/2017 Working Groups, 'Working Group - Social Bonds', https://www. icmagroup.org/assets/documents/Regulatory/Green-Bonds/GBP-WG-ToR-and-composition_Nov-2016_041116.pdf (accessed 20 April 2018). 
This reflects a structural issue evident in other types of impact investing: market participants generally have the discretion to determine whether to involve affected parties. ${ }^{167}$ By way of example, social impact bonds, another form of impact investing, rely on governments to facilitate stakeholder participation. ${ }^{168}$ Typically, a government agency is responsible for defining the desired policy outcome for the social project, which is executed by a non-governmental service provider. ${ }^{169}$ It is incumbent on the government agency to engage with stakeholders in the process of defining the social issue and the desired outcome of the financing and to require service providers to engage with affected communities during the term of the project. ${ }^{170}$

\section{External Assurance}

The SBPs do not provide prescriptive rules or authoritative guidance regarding the form or substance of measurement and reporting practices. Rather, the SBPs facilitate the dissemination of best practices through a repository of reporting templates and a database of voluntarily submitted reports for prior issuances. ${ }^{171}$ Generally speaking, investors holding bonds have limited resources to monitor a firm's performance. ${ }^{172}$ Current practices in the social bond market present additional barriers to investor assessment. Most social bond issuers commit to use proceeds to finance categories of projects over the term of the social bond rather than specific projects. ${ }^{173}$ To date, social bond issuers have been predominantly development banks and commercial banks. ${ }^{174}$ Banks use proceeds from the sale of a social bond to extend loans to companies that address social needs or to local partner financial institutions that in turn make loans to companies. ${ }^{175}$

\footnotetext{
167 See Maximilian Martin, 'Building the Impact Investing Market: Drivers of Demand and the Ecosystem Conditioning Supply' in Lehner (ed.), note 12, 672, 681-85 (describing the impact investing ecosystem).

168 With a social impact bond, investors provide up-front capital for a social project (e.g., reducing prison recidivism, enhancing employment opportunities for vulnerable youth) and are paid a financial return upon the successful completion of the project. Jim Clifford and Tobias Jung, 'Social Impact Bonds: Exploring and Understanding an Emerging Funding Approach' in Lehner (ed.), note 12, 161, 169, 171-72; Deborah Burand, 'Globalizing Social Finance: How Social Impact Bonds and Social Impact Performance Guarantees Can Scale Development' (2013) 9 NYU Journal of Law \& Business 447, 453.

169 See Jitinder Kohli, Douglas J Besharov and Kristina Costa, 'What are Social Impact Bonds?', Center for American Progress (22 March 2012), https://cdn.americanprogress.org/wp-content/uploads/issues/2012/03/pdf/social_impact_ bonds_brief.pdf (accessed 20 April 2018).

170 See Social Finance UK, 'A Technical Guide to Developing Social Impact Bonds' (January 2013), 5, 9, https:// www.socialfinance.org.uk/sites/default/files/publications/technical-guide-to-developing-social-impact-bonds1.pdf (emphasizing stakeholder engagement as best practice).

171 International Capital Markets Association, note 16, 3. See International Capital Markets Association, Green, Social and Sustainability Bonds, Resource Centre, https://www.icmagroup.org/Regulatory-Policy-and-Market-Practice/greensocial-and-sustainability-bonds/resource-centre/ (accessed 20 April 2018).

172 Triantis and Daniels, note 69, 1088-89.

173 See, e.g., Inter-American Development Bank, note 75, 1-2 (designating any project approved by the IDB's management and/or executive directors that falls under one of 13 categories of human capital development under education, youth and employment).

174 Among the social bonds and sustainability bonds available on one publicly available database, nearly threequarters (18 out of 25) were issued by a bank. See Sustainalytics, 'Green and Social Bond Projects', https://www. sustainalytics.com/green-social-bond-services/\#BondProjects (accessed 20 April 2018).

175 See, e.g., International Finance Corporation, note 58, 11, 20 (describing use of proceeds reporting for its Inclusive Business Bonds and Banking on Women Bond programmes, respectively); Sustainalytics, note 88, 3.
} 
Any given bank-issued social bond may finance thousands of individual loans and projects. $^{176}$

To aid investors, the SBPs recommend that issuers use external review in the form of second opinions, verification, certification and ratings. ${ }^{177}$ Second opinions are the predominant form of external assurance in the social bond market. A second opinion is an independent review of the framework of rules, regulations and guidelines used by a social bond issuer. ${ }^{178}$ A second opinion does not seek to measure social outcomes. Rather, it focuses on the process by which an issuer selects projects and investments to determine whether the selection criteria contribute to the social bond's stated social objectives. ${ }^{179}$ Second opinions are typically provided prior to the issuance of a social bond, and issuers may - but are not required to - obtain annual reviews during the term of the social bond. ${ }^{180}$ While immensely beneficial to market participants in the social bond market, second opinions are limited in their capacity to inform investors and stakeholders of human rights outcomes due to their static and voluntary nature.

\section{Impact-Maximizing Leverage}

Investors in the social bond market are limited in their ability to influence the day-to-day actions of companies. Unlike shareholders and other equity owners, bond holders do not enjoy voting or other governance rights, thereby inhibiting their ability to exercise leverage. ${ }^{181}$ Another potential source of leverage for bond holders is covenants in bond contracts that restrict the rights of issuers to take certain actions. ${ }^{182}$ These covenants are not prevalent in the social bond market, and the SBPs do not address the possibility of including them. ${ }^{183}$

The foregoing assessment shows how the SBPs fall short of ensuring that social bonds align with human rights in accordance with this article's three-part framework. In light of these deficits, the following discussion explores how the existing governance system can be improved.

\section{Optimizing the Human Rights Impact of Social Bonds}

The broad public mission of social bonds stands in juxtaposition to the private capital markets in which they are sold, marketed and traded. This dynamic highlights a fundamental question in business and human rights: whether binding legal obligations on corporations and other market actors are necessary to regulate new kinds of commercial

\footnotetext{
176 See, e.g., The Instituto de Crédito Oficial, 'Social Bond Reporting', https://www.ico.es/documents/19/1213011/ ICO+Loan+Portfolio+Summary+2017+-+04-11-2017+-+Final.pdf/811130fc-5acd-40ba-afd0-2f5db159bd0a (accessed 20 April 2018) (noting that 11,927 projects were supported by a single 500 euro social bond).

177 International Capital Markets Association, note 16, 4.

178 Cicero, 'Framework for CICERO's “Second Opinions” on Green Bond Investments' (2016) 2, https://www.cicero. uio.no/file/2/CICERO\%20Second\%20Opinion\%20Framework\%20280416.pdf/download (accessed 20 April 2018).

179 See ibid, 5.

180 Sustainalytics, 'Bond Services, Annual Compliance Reviews', https://www.sustainalytics.com/green-social-bondservices/\#BondServices (accessed 20 April 2018)

181 See Organisation for Economic Cooperation and Development, note 99, 37.

182 See ibid.

183 See Yakov Amihud, Kenneth Garbade and Marcel Kahan, 'A New Governance Structure for Corporate Bonds' (1999) 51 Stanford Law Review 447, 462-65 (explaining why bond covenants are relatively permissive).
} 
activity. ${ }^{184}$ The human rights shortcomings of the social bond market arguably suggest that government regulation should incorporate private governance regimes and transform voluntary standards into mandatory rules. ${ }^{185}$ However, incorporation and centralization may stifle the growth of the social bond market ${ }^{186}$ and even hinder compliance. ${ }^{187}$

Notwithstanding this debate, there is substantial policymaking space between reliance on industry-based self-regulation and the imposition of regulatory mandates under public law. In between these poles, businesses have a responsibility to help protect human rights and seek the realization of human rights within their own respective capabilities and irrespective of their legal obligations. ${ }^{188}$ While issuers and investors qua corporations may not have an affirmative legal obligation to prioritize sustainable development, they can collaborate with regulators and other stakeholders to address structural human rights deficits in their own activities. ${ }^{189}$ Social bonds, as a new and emerging approach to impact investing, rely on voluntary initiatives such as the SBPs and second opinions. Reforms to these existing governance regimes that selectively incorporate public intervention - without depending on new legal mandates - will help ensure that this financial innovation serves the human rights principles on which sustainable development is based. ${ }^{190}$

First, to enhance investor assurance, the social bond market should expressly draw on human rights assessment frameworks. For example, the Sustainable Development Solutions Network (SDSN) serves as the foundation for integrated global, national, regional and thematic monitoring of progress towards the SDGs. ${ }^{191}$ In order to align the SDGs with investor-oriented metrics in the social bond market, the SBPs could coordinate with initiatives under the SDSN in order to ensure that human rights impacts are incorporated into investor assurance. ${ }^{192}$ As a preliminary step towards that end, the Executive Committee that governs the SBPs has set out to map specific SDGs to eligible categories for use of proceeds from the sale of social bonds. ${ }^{193}$ To ensure that metrics are equitable and accountable, there should be broad and inclusive fora in which goals and trade-offs can be debated. Multilateral development banks and leading bilateral development agencies - which have substantial experience and well-established

\footnotetext{
184 See Michael A Santoro, 'Business and Human Rights in Historical Perspective' (2015) 14 Journal of Human Rights 155, 158 (noting the divide between proponents of legal and moral approaches).

185 David Vogel, 'Private Global Business Regulation' (2008) 11 Annual Review of Political Science 261, $267-68$.

186 See, e.g., Marc Jones, 'Don't Strangle Green Bond Market, EBRD Urges Regulators' Reuters (5 July 2016), https://uk.reuters.com/article/uk-markets-greenbonds-ebrd-idUKKCNOZL2CQ (accessed 20 April 2018).

187 See Abbott and Snidal, note 105, 551 (noting the ability of private and public-private hybrid governance regimes to enhance compliance).

188 See Wettstein, note 143, 756-59.

189 See Florian Wettstein, 'Normativity, Ethics, and UN Guiding Principles on Business and Human Rights: A Critical Assessment' (2015) 14 Journal of Human Rights 162, 174.

190 See Christian Voegtlin and Andreas G Scherer, 'Responsible Innovation and the Innovation of Responsibility: Governing Sustainable Development in a Globalized World' (2015) 143 Journal of Business Ethics 227 (proposing reforms to ensure responsible innovation that contributes to sustainable development).

191 See Sustainable Development Solutions Network, 'Indicators and a Monitoring Framework for the Sustainable Development Goals' (15 May 2015), https://sustainabledevelopment.un.org/content/documents/2013150612-FINALSDSN-Indicator-Report1.pdf (accessed 20 April 2018).

192 See ibid, 16 (noting the joint initiative between the Global Reporting Initiative (GRI), the UN Global Compact (UNGC), and the World Business Council for Sustainable Development (WBCSD)).

193 International Capital Markets Association, 'Quarterly Newsletter of the Green \& Social Bond Principles' (April 2018), https://www.icmagroup.org/Emails/Inaugural_Newsletter_from_the_Green_\&_Social_Bond_Principles/index. html (accessed 20 April 2018).
} 
procedures for selecting, approving and monitoring projects - may be able to serve this convening role in conjunction with industry associations. ${ }^{194}$

Second, to facilitate external assurance, the social bond market should incorporate certification and enhance the accessibility of second opinions to stakeholders. The Climate Bonds Initiative (CBI) is the leading global certification regime in the green bond market. In order for a green bond to be certified by CBI, it must meet pre-issuance and post-issuance requirements under CBI's Climate Bonds Standard. ${ }^{195}$ Once certified by CBI, an issuer may use a CBI certification logo for a specific green bond issuance. ${ }^{196}$ The European Commission's implementation of an EU Green Bond Label may eventually be adapted to social bonds. ${ }^{197}$ While the SBPs recommend public disclosure of second opinions, issuers are permitted to keep them private. ${ }^{198}$ Requiring the disclosure of second opinions will aid investors that acquire social bonds on the secondary market after issuance. Consistent with the proposed EU Green Bond Standard, social bond issuers should be required to obtain some kind of external assurance and make the results of such reviews public. ${ }^{199}$

Third, to maximize the impact of investor leverage, governments can assist investors in deciding how and where to allocate their capital. For example, the social bond market can direct financing to social enterprises and other companies that generally lack funding opportunities equivalent to their conventional business counterparts. ${ }^{200}$ Enterprise-level earmarking would aid the identification of social projects insofar as the entire portfolios or operations of social enterprises may be deemed eligible for social bond financing. The SBPs could coordinate with GIIN, leading impact investment firms and government agencies to facilitate the identification of qualifying social enterprises, the pooling of resources to assist social enterprises in marketing and selling social bonds, and the mitigation of financial risk through subsidized underwriting or a syndicate. Furthermore, government development agencies could provide co-financing and financial guarantees to spur social bond financing in accordance with the SDGs. ${ }^{201}$ This market-making role is consistent with the SDGs' vision of international public finance as means to catalyse private financing. ${ }^{202}$ These collective measures will facilitate the exercise of leverage by reducing investors' informational and operational costs and promoting investor-investee engagement.

\footnotetext{
194 The World Bank, one of the pioneers of the green bond market, reports on the sustainability impact of green bonds on a project-by-project basis. See World Bank, Green Bond Impact Report (Washington, DC: World Bank, June 2016) 11-23, https://treasury.worldbank.org/cmd/pdf/WorldBankGreenBondImpactReport.pdf (accessed 20 April 2018).

195 Climate Bonds Initiative, 'Climate Bonds Standard Version 2.1' (January 2017) 6-9, https://www.climatebonds. net/files/files/Climate\%20Bonds\%20Standard\%20v2_1\%20-\%20January_2017.pdf (accessed 20 April 2018).

196 Ibid, 4.

197 European Union High-Level Working Group on Sustainable Finance, 'Financing a Sustainable European Economy: Final Report 2018' (EU Working Group Final Report) (2018) 34, https://ec.europa.eu/info/sites/info/files/ 180131-sustainable-finance-final-report_en.pdf (accessed 20 April 2018).

198 International Capital Markets Association, note 16, 4.

199 See EU Working Group Final Report, note 197, 32 (outlining the provisions of the proposed EU Green Bond Standard).

200 Bugg-Levine et al, note 53, 120.

201 See Climate Bonds Initiative, 'Scaling Up Green Bond Markets for Sustainable Development' (2015) 14, https:// www.climatebonds.net/files/files/GB-Public_Sector_Guide-Final-1A.pdf (accessed 20 April 2018) (calling for strategic bond issuances by public entities).

2022030 Agenda, note 1, 11, para 43.
} 


\section{Conclusion}

This article highlights the integral role of the global financial markets in enabling the fulfilment of sustainable development and the realization of human rights embedded therein. Due to the size of their assets and their sheer number, institutional investors wield considerable influence over corporate conduct - and in certain cases, over states in various contexts. By analysing the nascent yet rapidly growing social bond market, this article shows how impact investing can further sustainable development in a manner that maximizes the realization of human rights.

From a prescriptive perspective, this article underscores the urgent need for the human rights community to engage with financial market participants as new and innovative instruments and strategies emerge. The rise of impact investing presents a broad range of new opportunities to unleash financial capital in a manner that benefits human rights. ${ }^{203}$ Human rights advocates cannot wait for government regulation ex ante nor rely on judicial remedies ex post to address human rights shortcomings. On the flip side, for impact investors, corporate issuers, private standard setters and other market intermediaries, due consideration of human rights helps them identify and avoid commercial risks that may arise from violations of human rights. ${ }^{204}$ Furthermore, it enables them to think of their social objectives in a holistic manner that takes into account all of the consequences of a given impact investment, not just the ones expressly targeted by the financial instrument.

Going forward, this article's framework for evaluating impact investing constitutes one of a series of first steps. Drawing on the principles for investor assessment, external assurance and impact-maximizing leverage outlined in this article, future research can examine the integration of human rights in firm- and industry-based impact investing metrics under the SDGs, the benefits and costs of public certification, and the most effective and least costly methods of government steering of impact investing capital.

Of immediate need and particular relevance to the social bond market is ongoing research on its inter-relationships with broader private governance and public regulatory regimes that already include - or in the future may implement - more robust human rights measurement and accountability mechanisms. As the social bond market expands to include new financial products, issuers and investors, the ability of the SBPs to facilitate linkages with the OECD Guidelines for Multinational Enterprises, to cite one example, will be critical. The willingness and ability of institutional investors to apply human rights standards from other frameworks - or to seek greater accountability through the SBPs and existing external assessment frameworks - will be essential to determine the optimal combination of discretionary guidelines, prescriptive standards and mandatory rules.

\footnotetext{
203 David Kinley, Necessary Evil: How to Fix Finance by Saving Human Rights (New York: Oxford University Press, 2018) 101.

204 Peter Muchlinski, 'Implementing the New UN Corporate Human Rights Framework: Implications for Corporate Law, Governance, and Regulation' (2012) 22 Business Ethics Quarterly 145, 156 (noting overlap between human rights risk and commercial risks such as reputational damage and lawsuits).
} 